\title{
CYTOCHEMICAL EVIDENCE FOR RNA SYNTHESIS INHIBITION BY FUMAGILLIN*
}

\author{
STEPHEN T. JARONSKI** \\ Laboratory of Insect Pathology, Department of Entomology, \\ Cornell University, Ithaca, N.Y. 14850, U.S.A.
}

(Received for publication April 3, 1972)

\begin{abstract}
Evidence was obtained that fumagillin inhibits RNA synthesis in the microsporidian, Octosporea muscaedomesticae, a pathogen of the blow fly, Phormia regina. Infections, treated with $66 \mathrm{mg}$ fumagillin per liter of $5 \%$ sucrose for six hours, were compared to control octosporeoses of the same age with the following techniques: Giemsa stain, pyronin-methyl green, and acridine orange fluorescence. Staining reactions demonstrated an almost complete loss of material from the parasites' cytoplasm; RNase treatment of normal parasites identified this material as RNA. Parasite DNA remained unchanged after fumagillin treatment, as observed by the above techniques.
\end{abstract}

The clinical effects of fumagillin have been extensively investigated since the drug's isolation in 1949. A scattered spectrum of organisms has been found susceptible to fumagillin, including Entamoeba histolytica ${ }^{1)}$, various other enteric protozoa ${ }^{2)}$, Nosema $a_{p i s^{3)}}$, Perezia pyraustae ${ }^{4)}$, Toxoplasma ${ }^{5)}$, and Plasmodium gallinaceum ${ }^{6)}$. A number of tumors are also inhibited, offering a potential use for fumagillin in this area ${ }^{7,8)}$. Bacteria, fungi, and helminths, however, are insusceptible to the drug ${ }^{2)}$. Fumagillin has perhaps been most significant in the treatment of nosemosis in the honeybee ${ }^{\text {9), }}$ and, to a lesser extent, amoebiasis in $\operatorname{man}^{10}$.

Despite the large amount of research, little has been elucidated about the mechanisms of fumagillin's action and the reason for its scattered specificity. Work that has been published is of ten contradictory. KATZNELSON and JAMIESON ${ }^{11)}$ theorized that the "early motile stages" (sporoplasms) of the microsporidian N. apis, were killed prior to cellular invasion, while BAILEY ${ }^{3)}$ observed that the vegetative stages (schizonts) were killed by the drug. Working with E. histolytica in vitro, GoRdEEvA ${ }^{12)}$ concluded that RNA synthesis was halted after a 48-hour exposure to fumagillin. Similar effects were indicated with EHrLich ascites carcinoma ${ }^{13)}$. HARTwig and PrzeleckA ${ }^{14)}$, on the other hand, concluded that DNA synthesis was blocked in N. apis while RNA synthesis was unaffected. To further complicate the situation, VANDERMEER and GOCHNAUER ${ }^{15}$ have implicated interference with the fatty acid metabolism of N. apis.

* This study was part of research performed in fulfilment of the requirements toward the Master of Science degree, Cornell University, Ithaca, N.Y., and was supported in part by Research Grant Al 09714-03 from the National Institute of Allergy and Infectious Diseases, National Institutes of Health, awarded to Dr. John P. Kramer, Dept. of Entomology. Cornell University.

** Presently on leave of absence from Cornell University and serving with the United States Air Force. All correspondence should be addressed c/o Dept. of Entomology, Cornell University, Ithaca, N. Y. 14850. 
I had previously noted that fumagillin, as Fumadil-B (Abbott Laboratories), was effective in controling the microsporidian Octosporea muscaedomesticae Flu infecting laboratory colonies of black blow fly, Phormia regina (in preparation). In view of the confusion in the literature, I examined the cytochemistry of fumagillin's action on octosporeosis to determiue whether DNA or RNA synthesis was affected.

\section{Materials and Methods}

Spores of $O$. muscaedomesticae were derived from a laboratory stock using $P$. regina as the host. To remove bacterial contamination and debris, 1 treated spore suspensions according to MCLAUGhLIN and BELL ${ }^{16)}$ and resuspended them in $5 \%$ sucrose for administration to the flies. Newly emerged adult flies were infected per os after a 12-hour starvation period to remove weaklings and ensure rapid ingestion of the inocula. All P. regina were from disease-free stocks. The flies were grouped into units of $25 \sim 30$ individuals, each unit receiving $2.5 \sim 3.0 \times 10^{6}$ spores in one $\mathrm{ml}$ of $5 \%$ sucrose, following the method of $\mathrm{K}_{\text {RAMER }}{ }^{17)}$. Flies generally consumed the inocula within 3 or 4 hours. During the course of the experiment, the flies subsisted on a diet of powdered milk and sugar, and had free access to water.

In one-half the groups, the infection was allowed to progress for 9 days at which time I administered fumagillin (as Fumadil-B) at a concentration of $66 \mathrm{mg} / \mathrm{liter}$ of $5 \%$ sucrose. Duration of the antibiotic treatment was 12 hours.

Alimentary tracts were removed from several of such treated flies, as well as from control flies infected for the same duration but not treated with the antibiotic. Some of the guts were smeared on coverslips, fixed in methanol, and stained in Gremsa's fluid. Other guts were similarly prepared but were air-dried and stained with PAppenheimSaAthof's methyl green-pyronin stain. The remaining guts were washed in distilled water, frozen, and sectioned in an Ames Cryostat at $5 \mu$ thickness. These sections were stained with acridine orange ( $\mathrm{pH} 3.8$ ) for ultraviolet fluorescence microscopy.

I was also interested in following the development of the disease with and without fumagillin medication. Another experimental group was infected as previously, but in this case received continuous fumagillin treatment subsequent to infection. At 4-hour intervals, for 156 hours, the alimentary tracts of several of these flies and also controls were dissected, fixed in Bourn's, dehydrated, cleared in toluene, embedded in paraffin, and cut into into $1 \sim 2 \mu$ thick longitudinal serial sections. These I stained with Wolbach's modification of the GIEMSA stain, buffered azureosin ( $\mathrm{pH} 4.0 \sim 4.5$ ), and methyl greenpyronin.

\section{Results}

Smear preparations yield all stages of the microsporidian (for a description of the life cycle see 17). The normal parasite is marked by one or more large, distinct nuclei, the number depending upon the stage, and a cytoplasm which is strongly basophilic with GIEMSA stain (Fig. 1). Methyl green-pyronin staining demonstrates that the basophilia is due to the presence of ribonucleic acid in large amounts, as the cytoplasm is strongly pyrinophilic. Acridine orange fluorescence, with RNase treated controls, substantiates this observation. O. muscaedomesticae floresces a bright orange which is extinguished when sections of infected gut are incubated with $\mathrm{M} / 10$ ribonuclease at $37^{\circ} \mathrm{C}$ for one hour.

Parasites from treated infections show a marked difference in the staining properties of their cytoplasm. In GIEMSA preparations, most of the basophilia has disappeared (Fig. 2); the pyrinophilia has disappeared; and the orange fluorescence has 
Fig. 1. Normal Octosporea mucaedomesticae from a 5-day old infection, stained with Giemsa. (a sporonts, b sporoblasts, and c mature spores.)

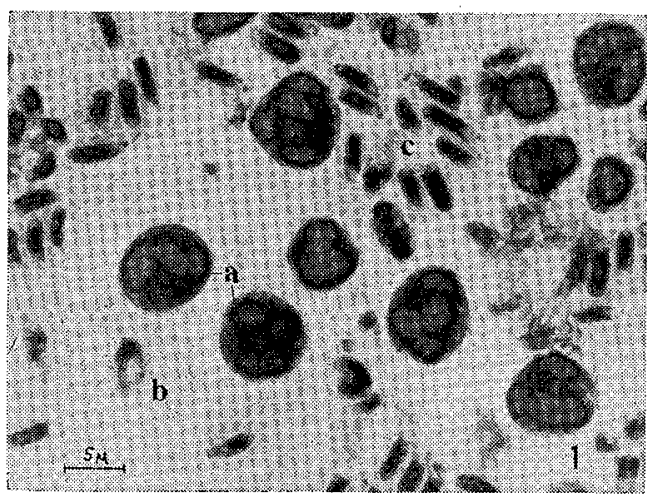

been extinguished. Late sporonts and sporoblasts are particularly affected. From these observations I would conclude that
Fig. 2. O. muscaedomesticae from a 5-day old infection which had been treated with fumagillin for 12 hours previous to fixation and staining.

Cells are stained with methyl green pyronin. Almost all cytoplasmic pyrinophilia (RNA) has disappeared. (a sporont, b diplokarya, and c sporoblasts.)

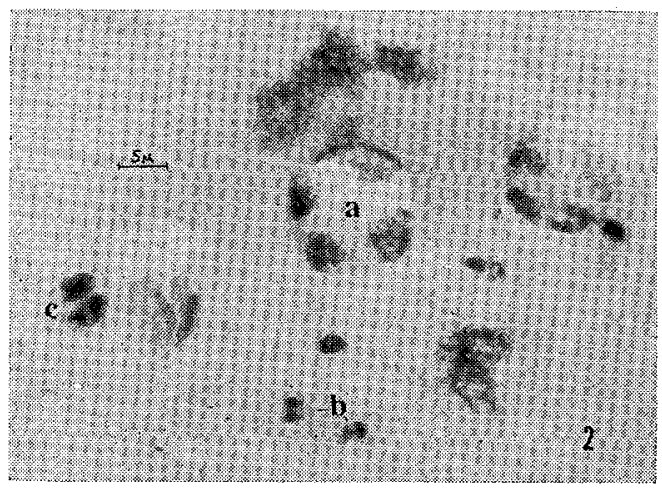

RNA has almost completely disappeared from the microsporidian during the 12-hour fumagillin treatment.

At the same time no changes in the DNA content of the parasites could be seen. Nuclei in both treated and untreated parasites appeared the same with all the staining protocols.

Histological observation of the progress of the infection showed an almost complete halt in the parasite's life cycle at the sporoblast stage $(48 \sim 56$ hours post-infection). Before that time few differences were observable between experimental and control octosporeoses. Beyond the 56-hour stage, however, few, it any parasites could be seen in the gut tissues, while in the controls, O. muscaedomesticae proliferated.

\section{Discussion}

In view of these results, the evidence of Hartwig and PrzeleckA ${ }^{14)}$, showing that DNA synthesis is solely affected, must be explained. The data of Gordeeva ${ }^{12)}$ and Tursunkho$\mathrm{DAEV}^{13)}$ both strongly indicate suppression of RNA transcription. Both authors noted that the ribonucleic acid content of their experimental organisms was drastically reduced following exposure to fumagillin, while DNA if affected, was so only at a much later time or at higher concentrations of the drug. In both cases cytochemical means (acridine orange fluorescence and the FeULGen reaction) were used to assay the drug's mode of action. Further observations by Mills ${ }^{18)}$ on a bacteriophage also infer interference with RNA synthesis. Phage production was affected only when treated with fumagillin before the latent period had passed. It is during this period that virus-specific RNA is produced to act a template for viral enzymes proteins ${ }^{19}$.

Hartwig and Przelecki ${ }^{14)}$, using ${ }^{3} \mathrm{H}$-thymidine incorporation as an assay of DNA synthesis in N.apis, observed that label uptake ceases with a one-hour exposure lo fumagillin in vivo. From their radioautographs one can see that not all thymidine uptake has ceased in the parasites, however. Furthermore, no mention is made of fumagillin's effect upon ${ }^{14} \mathrm{C}$-uracil incorporation, which would be indicative of RNA synthesis. It is only inferred rather that transcription has been inhibited, the authors stating only that it has been restored to the host epithelial cells. 
The apparent contradiction in these findings may be due to confusion between primary and secondary effects of fumagillin on the host-parasite system.

Cellular RNA is not permanent, but undergoes continuous turnover ${ }^{20)}$. Thus any disruption in the synthesis of this nucleic acid would be quickly evident by changes in the RNA content of the cell. In addition, RNA synthesis is independent of replication and there is evidence that the two processes are mutually exclusive on the same strand of template ${ }^{21}$. From these assumptions it seems unlikely that inhibition of DNA synthesis would result in the immmediate subsequent loss of RNA.

On the other hand, replication is preceded by the de novo synthesis of specific RNA coding for polymerase and accessory proteins. Actinomycin, by binding with template, blocks transcription during the $G_{1}$ period of interphase, and prevents enough DNA polymerase from being formed to allow replication ${ }^{22)}$. From my observations, supported by those of Gordenva and Tursunkhodaev, I believe that $f$ umagillin may act in analagous manner: inhibition of transcription and the formation of polymerase; concurrent loss of cytoplasmic RNA; cessation of replication; and finally cell death. This may explain the presence of both phenomena.

An additional observation during the course of these experiments may provide a clue as to the scattered specificity. In one fumagillin-treated fly, the infection at the 56hour stage was only partially inhibited by the antibiotic. Microsporidians in the apical regions of their host cells showed a distinct loss of basophilia with GIEMSA and buffered azure eosin techniques (Fig. 3). Those parasites in the basal areas, however, seemed to retain their normal basophilia. It would seem that the fumagillin had difficulty in entering the cell and a gradient of the drug had been established. The exact reason why this had happened in only one case and not in the others examined is unclear. Nevertheless, it may be that susceptibility to fumagillin may rest with its ability to penetrate the gut cells, at least with the microsporidians. The several species not susceptible are primarily non-gut parasites $^{23)}$. It is also known that fumagillin is not absorbed by the human intestinal tract ${ }^{24)}$. This hypothesis, however, remains to be definitively tested.

\section{References}

1) MoGowen, M. C.; M. E Caleender \& J.F. Lawlis : Fumagillin (H 3) a new antibiotic with amoebicidal properties. Science $113: 202,1951$

2) Killovgh, J. H.; G. B. Magill \& R. C. Smith: The treatment of amoebiasis with fumagillin. Science $115: 71 \sim 72,1952$

3) BaILeY, L.: The effect of fumagillin upon Nosema apis (ZANDER). Nature 171:212, 1953

4) Lewis, L. C. \& R. E. Lуксн : The treatment of Ostrinia nubilalis larvae with Fumadil-B to control infections caused by Perezia pyraustae. J. Invert. Pathol. $15: 43 \sim 48,1970$

5) Eyles, D. E. \& N. Coleman : Antibiotics in the treatment of toxoplasmosis. Am. J. Trop. Med. Hyg. $2: 64 \sim 69,1953$

6) Continey, G. R. \& J. Greenberg: Use of antibiotics in the treatment of malaria. Ann. N.Y. Acad. Sci. $55: 1075 \sim 1083,1952$

7) DiPaolo, J. A.; D.S. Tarbell \& G.E. Moore : Studies on the carcinolytic activity of fumagillin and some of its derivatives. Antibiot. Ann. 1958/1959:541 546, 1959 
8) Sugiura, K.: The effect of antibiotics on a spectrum of tumors. Antimicr. Agents. Ann. 1960: $924 \sim 942, \quad 1960$

9) Furgala, B. \& T. A. Gochnater: Chemotherapy of nosema disease. Am. Bee. J. 109:218 219,1969

10) $\mathrm{McH}_{\mathrm{ARDY}}, \mathrm{G}$. \& W.W. FRY : Antibiotics in the management of amoebiasis. J. Am. Med. Assoc. $154: 646 \sim 648,1954$

11) Katzinelson, H. \& C. A. Jameson: Control of nosema disease of honey bees with fumagillin. Science $115: 70 \sim 71,1952$

12) Gordeeva, I. M.: Changes of Entamoeba histolytica from a culture under the influence of emetine and fumagillin. Med. Parazitol. Parazit. Bolez. $36: 209 \sim 216,1967$

13) Tursunkhodzhaev, N. B.: Mechanism of action of the antitumor antibiotics olivomycin and fumagillin on the tumor cell. Antibiotiki $10: 314 \sim 318,1967$

14) Hartwig, A. \& A. Przelecka : Nucleic acids in the intestine in Apis mellifera infected with Nosema apis and treated with Fumagillin DCH : Cytochemical and autoradiographic studies. J. Invert. Pathol. $18: 331 \sim 336,1972$

15) Vandermeer, J. W. \& T. A. Gochnauer : The association of lipoidal materials with spores of Nosema apis. J. Invert. Pathol. $17: 284 \sim 285,1971$

16) Mclaughurn, R. E. \& M. R. Belt: Mass production in vivo of two protozoan pathogens, Mattesia grandis and Glugea gasti of the boll weevil, Anthonomus grandis. J. Invert. Pathol. $16: 84 \sim 88,1970$

17) Kramer, J. P.: The microsporidian Octosporea muscaedomesticae Flu, a parasite of calypterate muscoid flies in Illinois. J. Insect Pathol. $6: 331 \sim 342,1964$

18) MiLls, R.F.N.: The action of fumagillin on a bacteriophage in Staphylococcus aureus. J. Gen. Microbiol. $19: 209 \sim 240,1955$

19) Nomura, M.; B. D. Hall \& S. Spiegelman : Characterization of RNA synthetized in Escherichia coli after bacteriophage T 2 infection. J. Mol. Biol. 2 : 306 319, 1960

20) Thompson, R.Y.; F. C. Heazy, W. C. Hutchinson \& J. N. Daridson: The deoxyribonucleic acid content of the rat cell nucleus and its use in expressing the results of tissue analysis, with particular reference to the composition of liver tissue. Biochem. J. $53: 469 \sim 472,1953$

21) Prescont, D. M. \& R. F. Krmble: Relation between RNA, DNA, and protein synthesis in the replicating nucleus of Euplotes. Proc. Natl. Acad. Sci. USA $47: 686 \sim 693,1961$

22) Limberman, 1.; R. Abrams \& P. Ove: Changes in the metabolism' of ribonucleic acid preceding the synthesis of deoxyribonucleic acid in mammalian cells cultured from the animal. J. Biol. Chem. $238: 3955 \sim 3962,1963$

23) Fox, R.M. \& J. WeISER : A microsporidian parasite of Anopheles gambiae in Liberia. J. Parasit. $45: 21 \sim 30,1959$

24) Rebstock, M. C.: Antibiotics in Medicinal Chemistry (A. Burger, ed. 2 nd Edit. Interscience Publ. Ltd., London) 1960 